\title{
Lectotypification of Merremia rhyncorhiza (Convolvulaceae)
}

\author{
R.R. Kolte ${ }^{*}$, V.B. Shimpale ${ }^{2}$ and M.K. Janarthanam ${ }^{1}$ \\ ${ }^{1}$ Department of Botany, Goa University, Goa - 403206, India. \\ ${ }^{2}$ Department of Botany, The New College, Kolhapur -416012, Maharashtra, India. \\ *E-mail: rutuja24kolte@gmail.com
}

\begin{abstract}
Merremia rhyncorhiza (Dalzell) Hallier f. (三Ipomoea rhyncorhiza Dalzell) (Convolvulaceae) is lectotypified here.

Keywords: Endemic, Lectotypification, Merremia
\end{abstract}

\section{Introduction}

The genus Merremia Dennst. ex Endl. (Convolvulaceae) is represented by c. 100 species, and distributed in the tropical regions of the world (Mabberley, 2017). In India, over 15 species are reported (Santapau \& Henry, 1973) and all of them occur in the Western Ghats (Nayar et al., 2014). As a part of the floristic studies on herbaceous endemic plants of lateritic plateaus of southern Konkan and Goa, senior author has collected a specimen belongs to the genus Merremia. A careful scrutiny of literature (Cooke, 1908; Almeida, 1990; Venkanna \& Kumar, 2001) revealed its identity as $M$. rhyncorhiza (Dalzell) Hallier f., the only endemic species of this genus found in India confined to seven different localities at low and high elevation lateritic plateaus of northern Western Ghats (Mishra \& Singh, 2001; Shimpale, 2010; Nayar et al., 2014; Singh et al., 2015). Further, it was found that the name is yet to be lectotypified.

Merremia rhyncorhiza (Dalzell) Hallier f., Bot. Jahrb. Syst. 16(4-5): 552. 1893 ("rhynchorrhiza"); Santapau, J. Bombay Nat. Hist. Soc. 47(2): 344. 1947; T. Cooke, Fl. Bombay 2: 239. 1908; S.M. Almeida, Fl. Savantwadi 1: 288. 1990; M.R. Almeida, Fl. Maharashtra IIIA/B: 341. 2001; Venkanna \& S. Kumar in N.P. Singh et al., Fl. Maharashtra 2: 477. 2001; Shimpale, J. Swamy Bot. Club 27: 79. 2010.

Ipomoea rhyncorhiza Dalzell, Hooker's J. Bot. Kew Gard. Misc. 3: 179. 1851. Lectotype (designated here): INDIA, Maharashtra, Talkat Ghat (as
Tulkut-Ghât), Dalzell s.n. (K000830863, image!; isolecto, K000830865, K001081776, images!). Fig. 1

Dalzell (1851) described Ipomoea rhyncorhiza based on his collection from Tulkut-Ghât (Talkat Ghat) from Banda in Maharashtra without citing the details of specimen. During the study, authors found three specimens of Dalzell's collections from Tulkut-Ghât housed at K [K000830863, K000830865, K001081776] with proper annotation of name by the author. Of these, the specimen bearing the barcode number K000830863 is complete and agrees well with the details provided in the protologue. Hence, it is designated here as the lectotype for the name, Ipomoea rhyncorhiza (三 Merremia rhyncorhiza) as per the Art. 9.2 of Melbourne Code (McNeill et al., 2012) and the other two specimens [K000830865, K001081776] can be considered as isolectotypes.

\section{Acknowledgements}

Authors sincerely acknowledge Dr. K.N. Gandhi, Senior Nomenclatural Registrar, HUH, Cambridge, for his helpful suggestions on the nomenclature of species. Authors also sincerely acknowledge the Board of Trustees of Royal Botanic Gardens, Kew, for permission to publish the image of selected lectotype. They are also grateful to Dr. S.S. Kambale, Assistant Professor, MVP Samaj's Arts, Commerce and Science College, Tryambakeshwar, for his comments on the manuscript. RRK is thankful to Rufford Foundation, for financial support. 


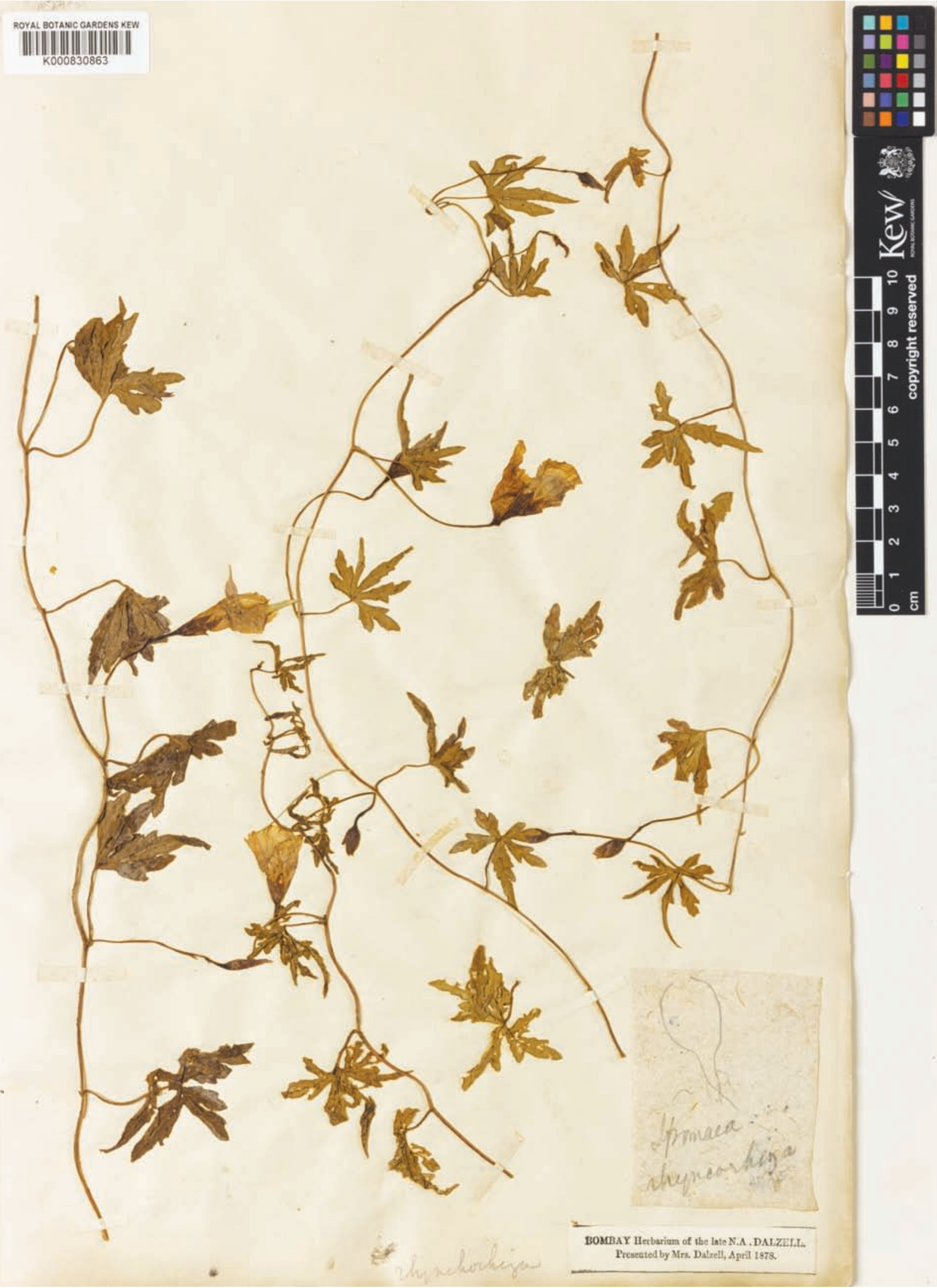

Fig. 1. Lectotype of Ipomoea rhyncorhiza Dalzell (K000830863). 


\section{Literature Cited}

Almeida, S.M. 1990. The Flora of Savantwadi, Maharashtra, India. Vol. 1. Scientific Publishers, Jodhpur. p.288.

Cooke, T. 1908. The Flora of the Presidency of Bombay. Vol. 2. Taylor \& Francis, London. p. 239.

Dalzell, N.A. 1851. Contribution to the botany of Western India. Hooker's J. Bot. Kew Gard. Misc. 3: $178-180$.

Mabberley, D.J. 2017. Mabberley's Plant-Book: A portable dictionary of plants, their classification and uses. Fourth Edition. Cambridge University Press, Cambridge.

McNeill, J., Barrie, F.R., Buck, W.R., Demoulin, V., Greuter, W., Hawksworth, D. L., Herendeen, P.S., Knapp, S., Marhold, K., Prado, J., Prud'homme van Reine, W.F., Smith, G.F., Wiersema, J.H. \& N.J. Turland 2012. International Code of Nomenclature for algae, fungi, and plants (Melbourne Code). Regnum Veg. 154. Koeltz Scientific Books, Königstein.

Mishra, D.K. \& N.P. Singh 2001. Endemic and Threatened Flowering Plants of Maharashtra. Botanical Survey of India, Calcutta.
Nayar, T.S., Rasiya Beegam, A. \& M. Sibi 2014. Flowering Plants of the Western Ghats of India. Vol. 1. Jawaharlal Nehru Tropical Botanic Garden and Research Institute, Thiruvananthapuram.

Santapau, H. \& A.N. Henry 1973. A Dictionary of the Flowering Plants in India. Council of the Scientific and Industrial Research, New Delhi.

Shimpale, V.B. 2010. Studies on distribution, status and reproductive capacity of Merremia rhyncorhiza - An endangered, endemic plant of Western Ghats. J. Swamy Bot. Club 27: 79-84.

Singh, P., Karthigeyan, K., Lakshminarasimhan, P. \& S.S. Dash 2015. Endemic Vascular Plants of India. Botanical Survey of India, Kolkata.

Venkanna, P. \& S. Kumar 2001. Convolvulaceae. In: Singh, N.P., Lakshminarasimhan, P., Karthikeyan, S. \& P.V. Prasanna (eds.), Flora of Maharashtra State, Dicotyledones. Vol. 2. Botanical Survey of India, Calcutta. pp. 437-489.

Received: 10.11 .2016

Revised and Accepted: 28.12.2017 